\title{
Cepharanthine inhibits angiogenesis and tumorigenicity of human oral squamous cell carcinoma cells by suppressing expression of vascular endothelial growth factor and interleukin-8
}

\author{
KOJI HARADA ${ }^{1}$, TARANNUM FERDOUS ${ }^{2}$, YASUTAKA ITASHIKI ${ }^{1}$, MICHIYO TAKII ${ }^{1}$, \\ TAKAMICHI MANO $^{1}$, YOSHIHIDE MORI ${ }^{1}$ and YOSHIYA UEYAMA ${ }^{1}$ \\ ${ }^{1}$ Department of Oral and Maxillofacial Surgery Yamaguchi University Graduate School of Medicine, \\ 1-1-1, Minamikogushi, Ube; ${ }^{2}$ Department of Therapeutic Regulation for Oral Tumors, Institute of \\ Health Bioscience, University of Tokushima Graduate School, Tokushima, Japan
}

Received September 16, 2008; Accepted December 15, 2008

DOI: 10.3892/ijo_00000417

\begin{abstract}
Cepharanthine is a biscoclaurine alkaloid extracted from Stephania cepharantha Hayata, which is widely used for the treatment of many acute and chronic diseases, and can exert antitumor effects on several human cancer cell lines. However, little is known about the detailed mechanisms of the antitumor activity of Cepharanthine. In the present study, we determined whether Cepharanthine could suppress angiogenesis and growth of human oral squamous cell carcinoma (OSCC) cells in vitro and in vivo. Cepharanthine significantly inhibited expression of two major pro-angiogenic molecules, vascular endothelial growth factor (VEGF) and interleukin-8 (IL-8), in cultured cells and in cells implanted into the subcutaneous tissue of nude mice. Also, Cepharanthine inhibited the nuclear factor- $\kappa \mathrm{B}(\mathrm{NF}-\kappa \mathrm{B})$ activity in human OSCC cells in vitro and in vivo. The decreased expression of VEGF and IL-8 correlated with decreased tumor cell growth and decreased vascularization in vitro and in vivo. These findings suggest that Cepharanthine can suppress angiogenesis and growth of OSCC cells by inhibiting expression of VEGF and IL-8 involved in the blockade of NF- $\mathrm{B}$ activity.
\end{abstract}

\section{Introduction}

Cancers of the oral cavity accounted for 274,000 cases in 2002 , with almost two-thirds of them in men. Also, they are the 11th most common cancer in males and 13th in females

Correspondence to: Dr Koji Harada, Department of Oral and Maxillofacial Surgery, Yamaguchi University Graduate School of Medicine, 1-1-1, Minamikogushi, Ube 755-8505, Japan

E-mail: harako@yamaguchi-u.ac.jp

Key words: Cepharanthine, antiangiogenesis, VEGF, IL-8, NF-кB in developed countries, and 6th in males and 10th in females in developing countries (1). Oral squamous cell carcinoma (OSCC) occupies the majority of oral cancers. OSCC is a significant public health problem throughout the world because oral function is very important for breathing, eating and conversation. In spite of recent advances in surgery, radiotherapy, chemotherapy and immunotherapy, the survival rate of OSCC is $<50 \%$ in the advanced stage $(2,3)$. In fact, we often detected local invasiveness and high rate of metastasis to cervical lymph nodes in patients with OSCC. In addition, we sometimes found distant metastasis or localized recurrence even after radical excision. Although surgery is the first choice of treatment, patients with unresectable cancers including recurrent cancers are not candidate for this approach. Chemotherapy is often used in these cases. Therefore, the development of a more effective therapeutic method for OSCC has continued.

Cepharanthine is one of the biscoclaurine alkaloids extracted from Stephania cepharantha Hayata (4), which has been widely used in Japan for treatment of many acute and chronic diseases; bronchial asthma, alopecia areata, leukopenia during radiation therapy or anticancer treatment (5). It has been reported that Cepharanthine exerts antitumor effects by increasing the immunological competence of the host $(6,7)$. It has also been reported that Cepharanthine increases the intracellular accumulation of the anticancer drug adriamycin through inhibiting its efflux from tumor tissue (8), while reducing its intracellular accumulation in normal tissue (9). Cepharanthine might be able to circumvent doxorubicinresistance $(10,11)$. Therefore, it is thought that Cepharanthine may be useful in cancer chemotherapy. In addition, Cepharanthine exerted antitumor effect by inducing apoptosis in a mouse leukemia cell line (12), an adenosquamous cell carcinoma cell line (13), and an oral squamous cell carcinoma cell line (14). However, little is known about the detailed mechanisms of antitumor activity of Cepharanthine in solid tumors, including OSCC.

The progression of OSCC is dependent in part on the formation of adequate vascular support, therefore we examined 
anti-angiogenicity for OSCC treatment. It has already been reported that angiogenesis showed a correlation with short survival and regional recurrence in oral cancer (15). Vascular endothelial growth factor (VEGF) has been shown to induce the proliferation of endothelial cells, increase vascular permeability, and prolong their survival $(16,17)$. In addition, since it has been reported that VEGF positivity is a useful predictor of poor prognosis in oral cancer, VEGF status may prove to be an important prognostic factor in head and neck cancer $(18,19)$. Interleukin-8 (IL-8), a chemo-attractant cytokine, has been shown to attract and activate neutrophils in inflammatory regions, and it is thought to be an angiogenic factor $(20,21)$.

Recent studies have demonstrated that inhibition of NF- $\mathrm{BB}$ $(\mathrm{NF}-\mathrm{\kappa B})$ activity in ovarian cancer cells can suppress angiogenesis and progressive growth by suppressing expression of VEGF and IL-8 (22). Interestingly, it was reported that Cepharanthine might inhibit activation of NF- $\mathrm{KB}$ in monocytic cells (23).

In this study, we tried to determine whether Cepharanthine could suppress angiogenesis and growth of OSCC cells by suppressing expression of VEGF and IL-8 involved in blockade of NF-kB activity in vitro and in vivo.

\section{Materials and methods}

Chemicals. Cepharanthine was obtained from Kaken Shoyaku Co., Ltd. (Tokyo, Japan). Cepharanthine was easily dissolved in complete culture medium and the antiproliferative activity of Cepharanthine stored in the medium was stable for at least 6 months at $4^{\circ} \mathrm{C}$ (data not shown).

Cells and culture. B88 cells were isolated from a patient with OSCC in our laboratory (24). HSC3 cells (OSCC) were obtained from American Type Culture Collection (Manassas, VA, USA). Bovine aortic endothelial cells (BAEC) were cloned from bovine aortas, cultured and characterised by Schor et al (25). B88 and HSC3 cells were cultured in DMEM supplemented with medium supplemented with $10 \%$ fetal bovine serum (FBS), $100 \mu \mathrm{g} / \mathrm{ml}$ streptomycin and $100 \mathrm{U} / \mathrm{ml}$ penicillin. BAEC were maintained on gelatinised dishes in DMEM supplemented with $10 \%$ FBS, 1 mM sodium pyruvate, non-essential amino acids $(81.4 \mu \mathrm{g} / \mathrm{l}), 2 \mathrm{mM}$ glutamine, 50 $\mathrm{mg} / \mathrm{ml}$ ascorbic acid, penicillin $(100 \mathrm{U} / \mathrm{ml})$ and streptomycin $(100 \mu \mathrm{g} / \mathrm{ml})$. All cells were incubated in a humidified atmosphere of $95 \%$ air and $5 \% \mathrm{CO}_{2}$ at $37^{\circ} \mathrm{C}$.

Animals. Female athymic nude mice with CAnN.Cg-Foxnlnu/ CrlCrlj genetic background (CLEA Japan, Inc. Tokyo, Japan) were purchased at 4 weeks of age and kept under sterile conditions in a pathogen-free environment. The mice were provided with sterile water and food ad libitum, and all manipulations were carried out aseptically inside a laminar flow hood.

MTT assay. Cells were seeded on 96-well plates (Falcon) at $5 \times 10^{3}$ cells per well in DMEM containing $10 \%$ FBS. After 1,2 and 3 days, the number of cells was quantitated by an assay in which MTT [3-(4, 5-dimethylthiazol-2-yl)-2, 5-diphenyltetrazolium bromide (Sigma)] was used (26).
Migration assay with Boyden chamber. Chemotaxis (directed migration) was evaluated in the Boyden chamber apparatus (Neuro-probe, Inc., Cabin John, MD, USA). Briefly, subconfluent cells were starved for $24 \mathrm{~h}$ and harvested with $0.05 \%$ trypsin containing $0.02 \%$ EDTA, washed twice with phosphate-buffered saline (PBS), and re-suspended at a final concentration of $5 \times 10^{5} / \mathrm{ml}$ in serum-free medium with $0.1 \%$ fraction $\mathrm{V}$ bovine serum albumin (BSA). PVP filters (Nuclepore Corp, Palo Alto, CA) of $8-\mu \mathrm{m}$ pore size were pre-coated with gelatin $(0.1 \mathrm{mg} / \mathrm{ml})$, rinsed in sterile water, and were used for assay. Bottom wells of the chamber were filled with $25 \mu 1$ of $10 \%$ FBS DMEM per well and covered with a gelatin-coated membrane, and then $50 \mu 1$ of cell suspensions, yielding 500 cells $/ \mu 1$, was added to the top wells. After $24 \mathrm{~h}$ of incubation, the membranes were stained with Giemsa solution. Cells on the upper surface of the filter were carefully removed with a cotton swab, and the cells that had migrated through the membrane to the lower surface were counted in 9 different fields under a light microscope at x 400 magnification. Each experiment was performed in triplicate wells and repeated 3 times.

Preparation of conditioned medium. Confluent 100-mm plates of cells were washed with PBS (-) and incubated with $10 \mathrm{ml}$ of fresh serum-free DMEM that was collected after an additional 24-96 $\mathrm{h}$ incubation with Cepharanthine contained DMEM. After low-speed centrifugation at 3,000 rpm $(1,000 \mu \mathrm{g})$ to remove cellular debris, each conditioned medium (CM) was concentrated 25 -fold by a Centricon membrane with a molecular-weight cut-off of 3,000 (Millipore Corp., Bedford, MA, USA).

Enzyme-linked immunosorbent assay (ELISA) for quantitative determination of VEGF and IL-8. VEGF and IL-8 contained in $\mathrm{CM}$ either from untreated control or from Cepharanthinetreated cells were measured by a microtiter-based sandwich enzyme immunoassay system, which is commercially available and specifically estimates the total amount of both factors. According to the protocol of the ELISA kit, concentrated CM was subjected to the ELISA using immunoassay kits for VEGF (BioSource International Inc., CA, USA) and IL-8 (BioSource International).

Relative real-time mRNA quantitation. Total RNA was isolated from cells with Isogen (Nippon Gene Co., Toyama, Japan). Total RNA (1 $\mu \mathrm{g})$ was reversely transcribed into complementary DNA (cDNA) by Moloney murine leukemia virus reverse transcriptase, using random hexamer primers (Gibco BRL, Rockville, MD, USA). Real-time RT-PCR measurement of VEGF and IL-8 cDNA was performed in the Taqman detection protocol in an ABI PRISM 7000 sequence detector (Applied Biosystems, Foster City, CA, USA). The results for VEGF and IL-8 real-time RT-PCR assay were normalized to those obtained for the corresponding $\beta$-actin mRNA, providing a relative quantitation value. Taqman probes were obtained from Applied Biosystems and the following sequences were used: VEGF, 5'-AACTTCACCACTTCGT GATGATTCTGCCCT; IL-8, 5'-CTTGGCAAAACTGCA CCTTCACACAGA; ß-actin, 5'-CCGCCGATCCACACGG AGTACTTG. PCR was performed in a total volume of $50 \mu 1$ 
of each amplification mixture containing $1 \mu \mathrm{l}$ of each RT product, $25 \mu \mathrm{l}$ of Universal master mix (Applied Biosystems), $200 \mathrm{nM}$ VEGF or IL-8 forward and reverse primers, $100 \mathrm{nM}$ fluorogenic probe. Each assay included a standard curve, a no-template control and cDNA samples in triplicate. The standard curve was generated by 5 -fold dilutions of pooled cDNA obtained from cells. The relative expression level of VEGF or IL-8 was expressed as the ratio of VEGF/ß-actin or IL-8/ß-actin in arbitrary units.

Western blot analysis. Cytosolic protein was isolated from control and Cepharanthine-treated B88 cells. The soluble protein was separated on $10 \%$ SDS-PAGE by electrophoresis and electrophoretically transferred onto PVDF membrane (Bio-Rad, Hercules, CA, USA), and the membrane was incubated with a 1:500 dilution of the rabbit polyclonal antibody against VEGF (A-20: Santa Cruz Biotechnology, Inc., CA, USA) and the rabbit polyclonal antibody against IL-8 (Santa Cruz Biotechnology) as the primary antibody, and an Amersham ECL kit (Amersham Pharmacia Biotech). Also, anti- $\alpha$-tubulin monoclonal antibody (Zymed Laboratories, San Francisco, CA, USA) was used for normalization of Western blot analysis.

Microwell colorimetric $N F-\kappa B$ assay. The assay was performed

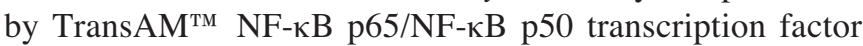
assay kits (Active Motif, Carlsbad, CA, USA) according to the manufacturer's instructions. Briefly, nuclear extracts were prepared using Nuclear and Cytoplasmic Extraction Reagents (NE-PER, Pierce Biotechnology, IL, USA) and placed on ice. Step 1: binding of NF- $\mathrm{BB}$ to its consensus sequence. p65 $(20 \mu 1)$ diluted in lysis buffer or $20 \mu 1$ of cell extract were incubated with $30 \mu \mathrm{l}$ of binding buffer [ 4 mM HEPES pH 7.5, $100 \mathrm{mM} \mathrm{KCl}, 8 \%$ glycerol, $5 \mathrm{mM}$ DTT, $0.2 \%$ BSA, $0.016 \%$ poly $\mathrm{d}(\mathrm{IC})]$ in microwells coated with the probes containing the NF- $\mathrm{KB}$ binding consensus. After $1 \mathrm{~h}$ incubation at room temperature with a mild agitation $(200 \mathrm{rpm}$ on an IKA MS2 vortex), microwells were washed 3 times with PBS (-)+ $0.1 \%$ Tween-20. Step 2: binding of primary antibody. Rabbit antiNF-кB antibodies $(100 \mu \mathrm{l})$, diluted 1000 times in a $10 \mathrm{mM}$ phosphate buffer ( $\mathrm{pH} 7.4$ ) containing $50 \mathrm{mM} \mathrm{NaCl}$ and $1 \%$ non-fat dried milk, were incubated in each well for $1 \mathrm{~h}$ at room temperature. Microwells were then washed 3 times with $200 \mu 1$ PBS (-) $+0.1 \%$ Tween-20. Step 3: binding of secondary antibody. Peroxidase-conjugated goat anti-rabbit IgG (100 $\mu \mathrm{l}$ and $1 \%$ non-fat dried milk, were incubated in each well for $1 \mathrm{~h}$ at room temperature. Microwells were then washed 4 times with $200 \mu \mathrm{l}$ PBS (-) $+0.1 \%$ Tween-20. Step 4: colorimetric reaction. Tetramethylbenzidine $(100 \mu \mathrm{l})$ was incubated for $10 \mathrm{~min}$ at room temperature before adding $100 \mu \mathrm{l}$ of stopping solution. Optical density was then read at $450 \mathrm{~nm}$, using a $650-\mathrm{nm}$ reference wavelength, with a Bio-Rad microplate reader (Bio-Rad) (27).

In vitro angiogenesis assay. An in vitro angiogenesis assay kit (Kurabo, Osaka, Japan) was used according to manufacturer instructions. Briefly, the basal medium including VEGF (final concentration $10 \mathrm{ng} / \mathrm{ml}$ ) was used for the human umbilical vein endothelial cell (HUVEC)/fibroblast co-culture. The medium including Cepharanthine was changed every 3 days.
After 11 days, cells were fixed at room temperature in $70 \%$ ethanol and stained with anti-CD31 antibody according to the manufacturer's protocol.

Tumor measurements and data analysis. Cultured tumor cells $\left(1 \times 10^{6}\right)$ were suspended in $0.1 \mathrm{ml}$ of serum-free medium and injected into the subcuta neous tissue of 5-week-old nude mice using a 27-gauge needle. The size of the tumors were determined by first measuring length $(\mathrm{L})$ and width $(\mathrm{W})$ and then calculating the volume $\left(0.5 \times \mathrm{L} \mathrm{x} \mathrm{W}^{2}\right)$ every 2 days. The body weight of the mice was also measured every 2 days. Experiments were started when tumors reached an average volume of about $100 \mathrm{~mm}^{3}$. The mice were sacrificed at 21 days by cervical dislocation.

Immunohistochemistry. Subcutaneous tumors harvested at autopsy were processed for immunostaining using a rabbit polyclonal antibody against VEGF, IL-8 and p65 (Santa Cruz Biotechnology), and a mouse monoclonal antibody against CD34 (Santa Cruz Biotechnology), and appropriate peroxidaseconjugated anti-mouse or rabbit IgG second antibody. The slides were examined in a bright-field microscope. A positive reaction was indicated by a reddish-brown precipitate in the cytoplasm. Negative controls were done using nonspecific IgG.

Vascularity. Vascularity was determined by the stereological method of point counting, which estimates the volume occupied by the vasculature (28). An eyepiece graticule that contained 100 points was used. CD34-positive vessels intersecting the points were counted in 15 random fields across each section (i.e. 1500 points examined), and the results are expressed as the mean percentage \pm SD. Vascularity was quantified in the stroma close to the epithelium, up to $\sim 750 \mu \mathrm{m}$ from the basal lamina.

Statistics. The significance of the in vitro and in vivo results was determined by the Mann-Whitney U test.

\section{Results}

Effect of Cepharanthine on in vitro cell growth. We tested the effect of Cepharanthine at seven concentrations on in vitro cell growth of B88 and HSC3 cells. A low concentration of Cepharanthine $(0.1-1.0 \mu \mathrm{g} / \mathrm{ml})$ did not suppress the cell growth of B88 and HSC3 cells. However, high concentrations of Cepharanthine $(2.0-20.0 \mu \mathrm{g} / \mathrm{ml})$ significantly suppressed the growth of B88 and HSC3 when compared with that of control (Cepharanthine $0 \mu \mathrm{g} / \mathrm{ml}$ ) (Fig. 1). Moreover, the growth of BAEC was not suppressed in a low concentration of Cepharanthine $(0.1-2.0 \mu \mathrm{g} / \mathrm{ml})$, but was suppressed in a high concentration of Cepharanthine (5.0-20.0 $\mu \mathrm{g} / \mathrm{ml}$ ) (Fig. 2).

Effect of Cepharanthine on in vitro cell migration. Cell migration is an essential process involved in tumor angiognesis as well as tumor invasion and metastasis. A low concentration of Cepharanthine $(0.1-2.0 \mu \mathrm{g} / \mathrm{ml})$ did not suppress the cell migration of B88, HSC3 and BAEC. However, higher concentrations of Cepharanthine $(5.0-20.0 \mu \mathrm{g} / \mathrm{ml})$ significantly suppressed the migration of B88, HSC 3 and BAEC when compared with that of control (Cepharanthine $0 \mu \mathrm{g} / \mathrm{ml}$ ) (Fig. 3). 


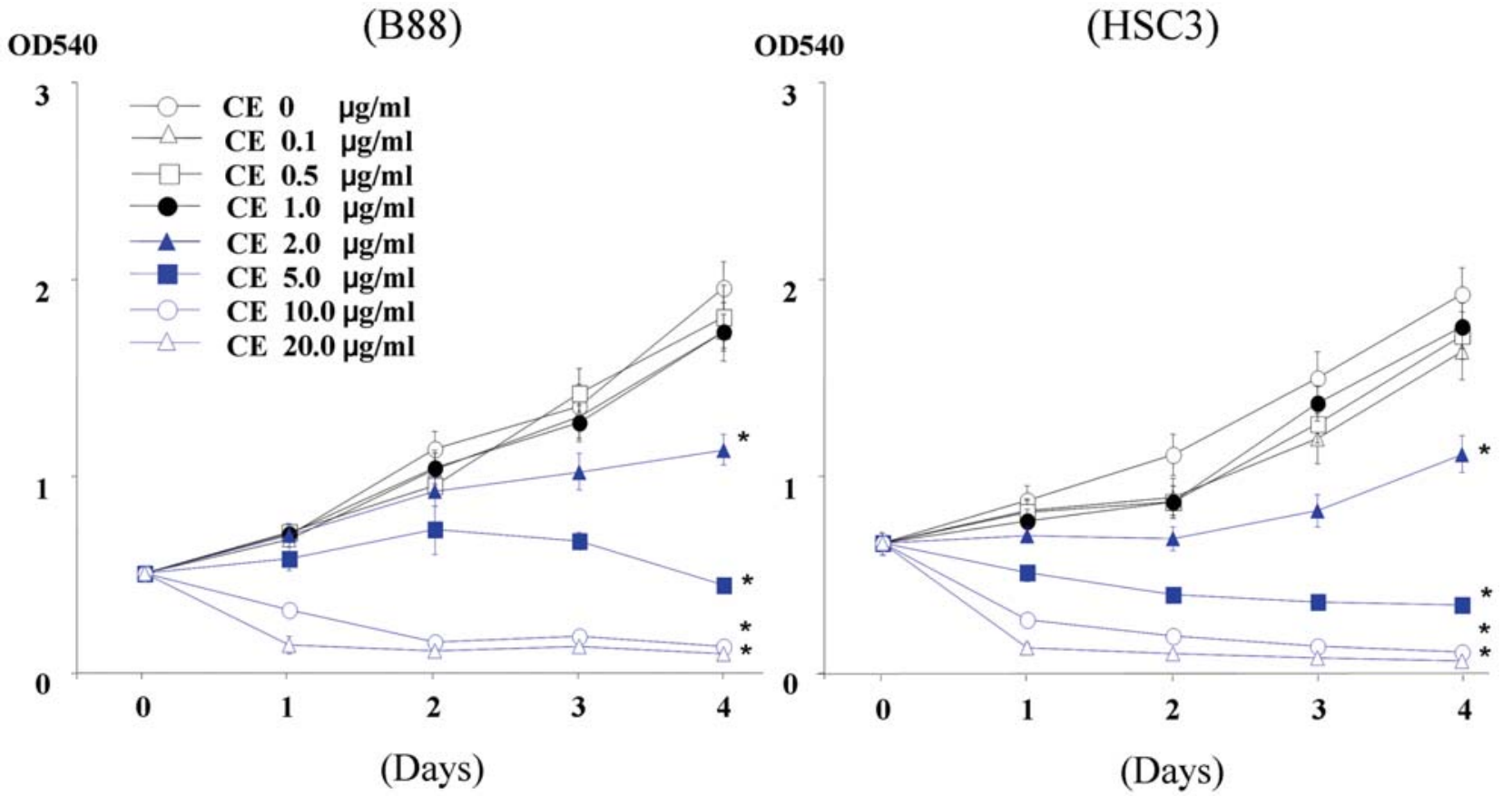

Figure 1. Growth inhibitory effect of Cepharanthine on B88 and HSC3 cells. Cells ( $3 \times 10^{3}$ cells/well) were seeded into 96-well plates and exposed to Cepharanthine at the indicated concentration in $10 \%$ fetal bovine serum-supplemented medium. At different time intervals, cells were counted using a microplate reader. Each data point represents the mean of six independent determinations.

\section{OD540}

(BAEC)

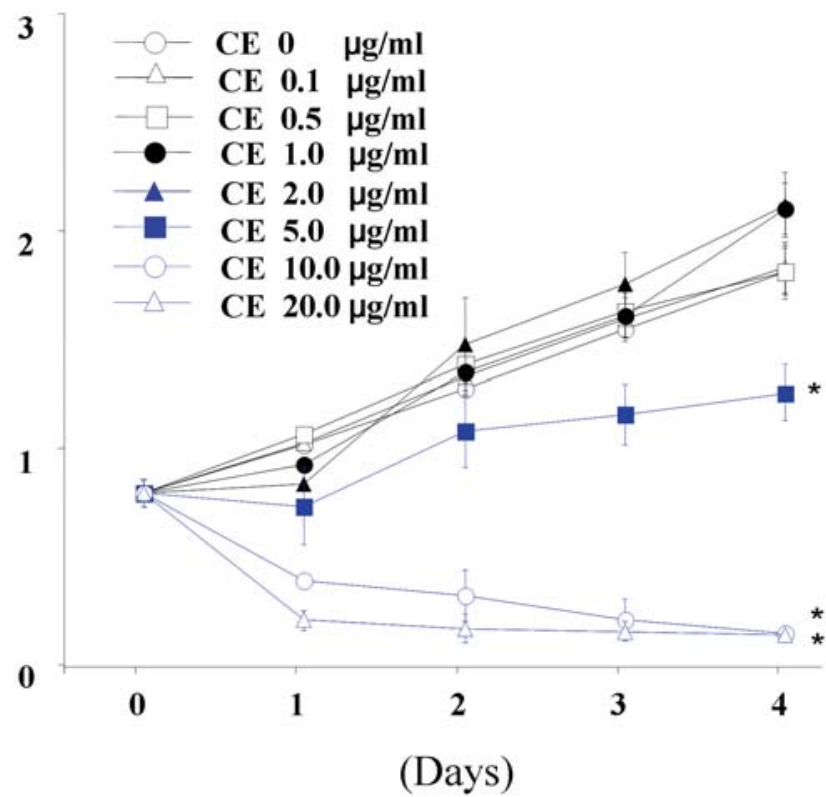

Figure 2. Growth inhibitory effect of Cepharanthine on BAEC cells. Cells $\left(3 \times 10^{3}\right.$ cells/well) were seeded into 96 -well plates and exposed to Cepharanthine at the indicated concentration in $10 \%$ fetal bovine serumsupplemented medium. At different time intervals, cells were counted using a microplate reader. Each data point represents the mean of six independent determinations.

Effect of Cepharanthine on VEGF and IL-8 production. We next investigated whether the Cepharanthine-treated B88 or HSC3 cells would result in a reduced expression of VEGF and
IL-8. Figs. 4 and 5 show the quantities of VEGF and IL-8 secreted by cells as determined by ELISA. Secretion of VEGF and IL- 8 was significantly reduced in the Cepharanthinetreated $\mathrm{B} 88$ or HSC 3 cells relative to untreated B 88 or HSC 3 cells on 48-96 h treatments. In addition, as shown in Fig. 6, Western blot analysis demonstrated that the expression of VEGF and IL- 8 by Cepharanthine decreased in a timedependent manner after $72 \mathrm{~h}$ of treatment. This effect of Cepharanthine on decreasing VEGF and IL-8 levels was coincidental with Cepharanthine-induced suppression of VEGF and IL- 8 mRNA by real-time RT-PCR analysis (Fig. 7).

Effect of Cepharanthine on $N F-\kappa B$ activation. It is thought that head and neck SCC cells show significantly higher NF-кB binding activity than normal oral epithelial and salivary gland cells (29). We therefore investigated whether Cepharanthine could decrease the NF- $\kappa \mathrm{B}$ binding activity on B88 cells. In the case of untreated $\mathrm{B} 88$ cells, $\mathrm{NF}-\mathrm{\kappa B}$ activation was not detected. When B88 cells were treated with TNF- $\alpha$ (50 ng/ml), NF-кB binding activity was markedly increased at $0.5 \mathrm{~h}$ after treatment. Moreover, incubation with $20 \mu \mathrm{g} / \mathrm{ml}$ of Cepharanthine fully suppressed the TNF- $\alpha$-induced NF- $\mathrm{KB}$ activation (Fig. 8).

Effect of Cepharanthine on angiogenesis in vitro. To investigate the effect of Cepharanthine on induced antiangiogenesis in oral tumors, we examined the effects of Cepharanthine on HUVECs. In vitro angiogenesis assays showed that the basal medium including VEGF (final concentration $10 \mathrm{ng} / \mathrm{ml}$ ) promoted tubule formation in HUVECs, 11 days after treatment, which was $\sim 30 \%$ inhibited by the addition of Cepharanthine $(1.0 \mu \mathrm{g} / \mathrm{ml}), \sim 90 \%$ inhibited by the 

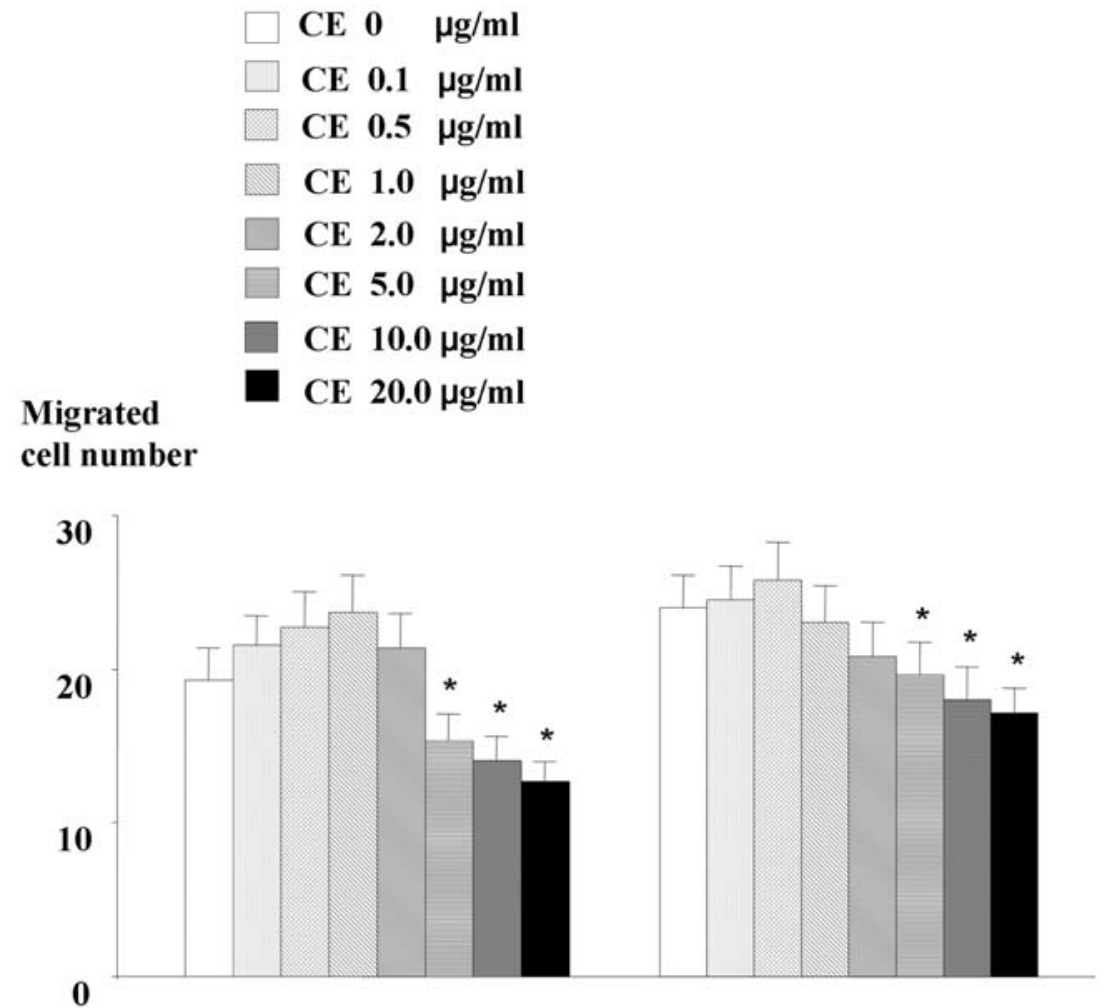

B88

HSC3
Migrated
cell number

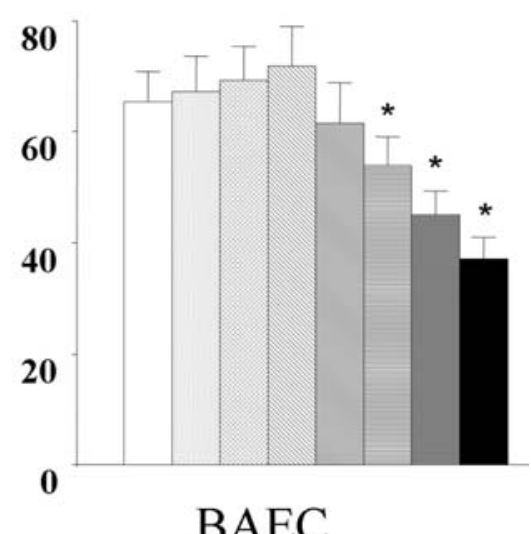

Figure 3. Migration inhibitory effect of Cepharanthine on B88, HSC3 and BAEC cells. Cell migration was evaluated by using 48-well modified Boyden chamber. After $24 \mathrm{~h}$ (B88 and HSC3) or $4 \mathrm{~h}$ (BAEC) of incubation, the migrated cells in each treatment were counted in 9 different fields under a light microscope.

\section{(B88)}

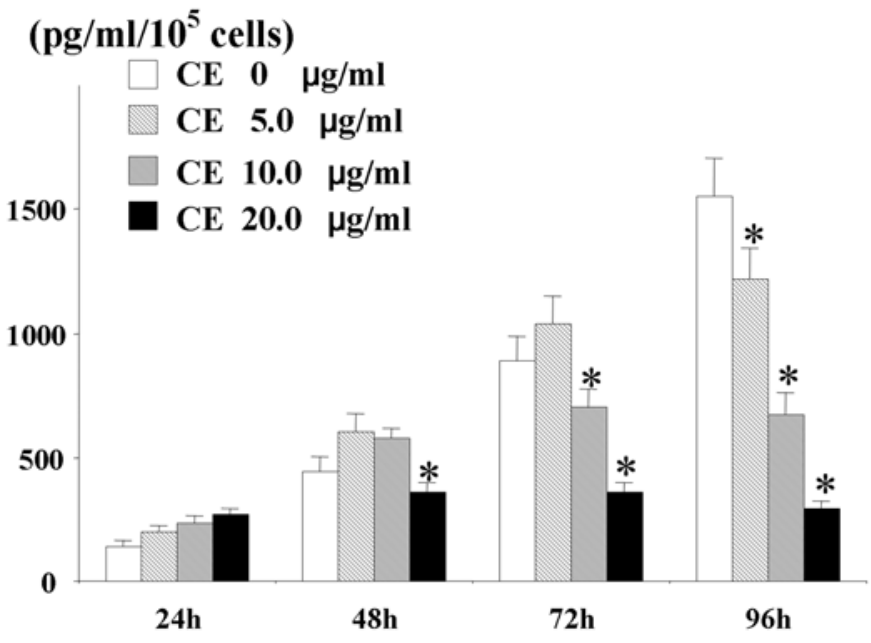

(HSC3)

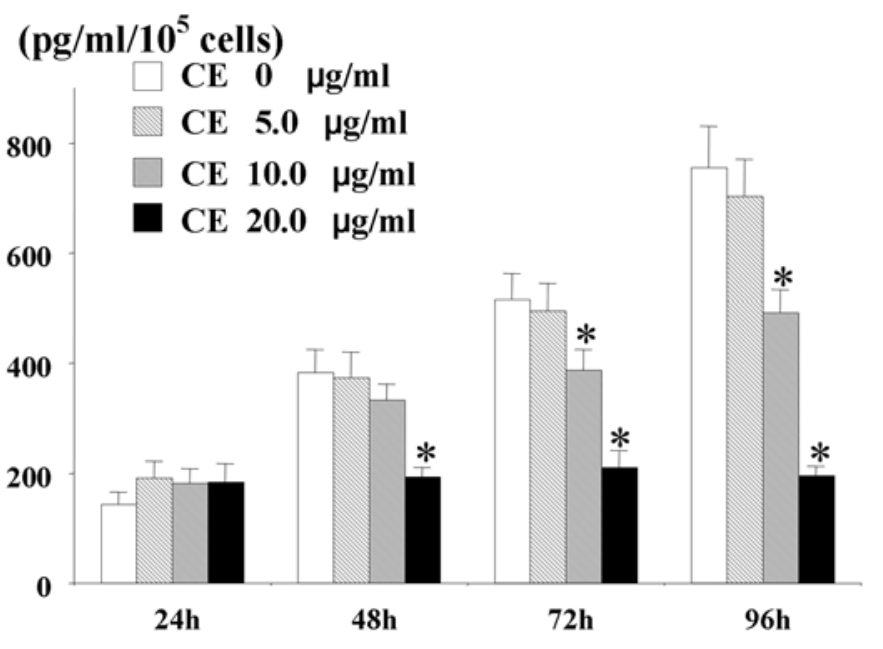

Figure 4. Quantitative determination of VEGF secreted by Cepharanthine-treated B88 cells with ELISA. For detection of secretion of VEGF, cells were seeded into six-well plate, and after $24 \mathrm{~h}$, medium was replaced. B88 cells were then cultured with standard medium of cancer cells for $24,48,72$ and $96 \mathrm{~h}$ in the absence or presence of $20 \mu \mathrm{g} / \mathrm{ml}$ Cepharanthine. Supernatants were then cleared and subjected to a commercial VEGF or IL-8 immunoassay. Data represent the means \pm SD from three independent experiments. ${ }^{*} \mathrm{P}<0.01$ when compared with that of control by Mann-Whitney $\mathrm{U}$ test.

addition of Cepharanthine $(5.0 \mu \mathrm{g} / \mathrm{ml}), \sim 95 \%$ inhibited by the addition of Cepharanthine $(10.0 \mu \mathrm{g} / \mathrm{ml})$, and $\sim 98 \%$ inhibited by the addition of Cepharanthine $(20.0 \mu \mathrm{g} / \mathrm{ml})$ (Fig. 9).
Effect of Cepharanthine on nude mice tumor growth. The therapeutic effect of Cepharanthine on B88 tumor-bearing nude mice is shown in Fig. 10. When the Cepharanthine 

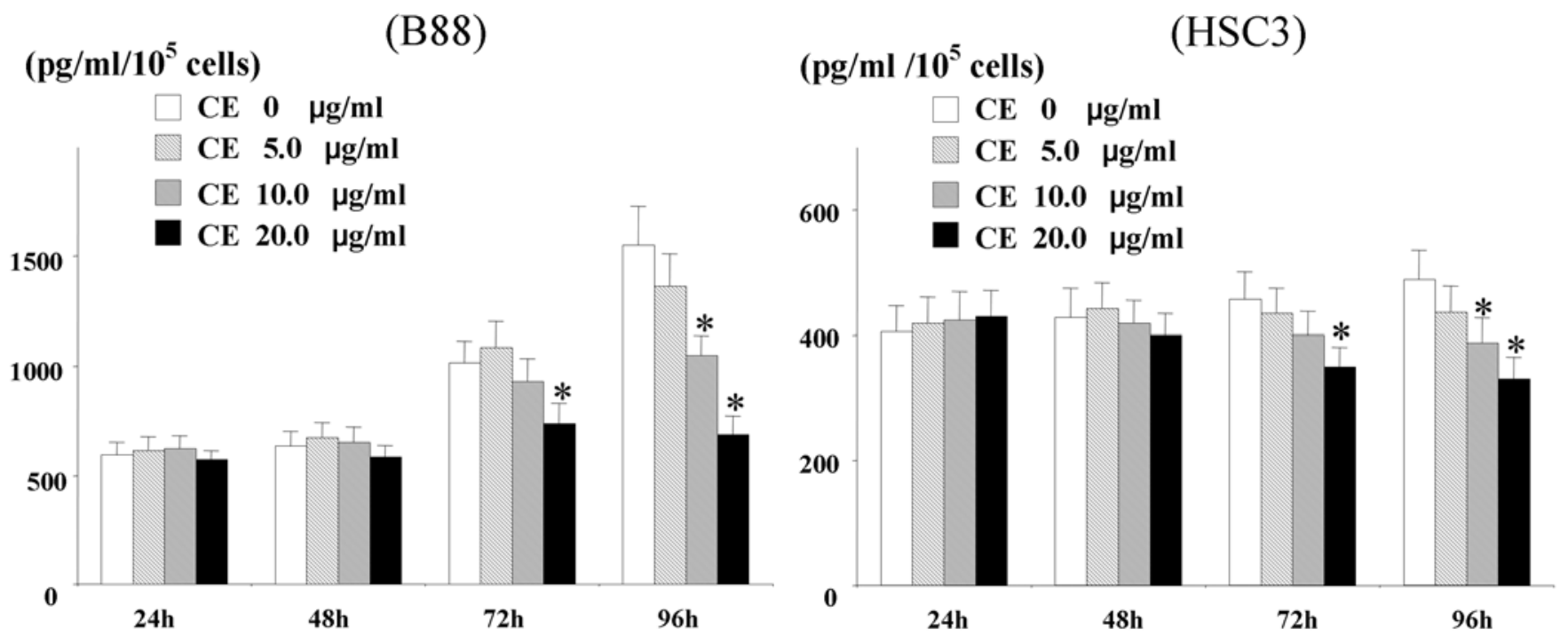

Figure 5. Quantitative determination of VEGF secreted by Cepharanthine-treated B88 cells with ELISA. For detection of secretion of VEGF and IL-8, cells were seeded into six-well plate, and after $24 \mathrm{~h}$, medium was replaced. B88 cells were then cultured with standard medium of cancer cells for $24,48,72$ and $96 \mathrm{~h}$ in the absence or presence of $20 \mu \mathrm{g} / \mathrm{ml}$ Cepharanthine. Supernatants were then cleared and subjected to a commercial VEGF or IL-8 immunoassay. Data represent the means \pm SD from three independent experiments. ${ }^{*} \mathrm{P}<0.01$ when compared with that of control by Mann-Whitney U test.

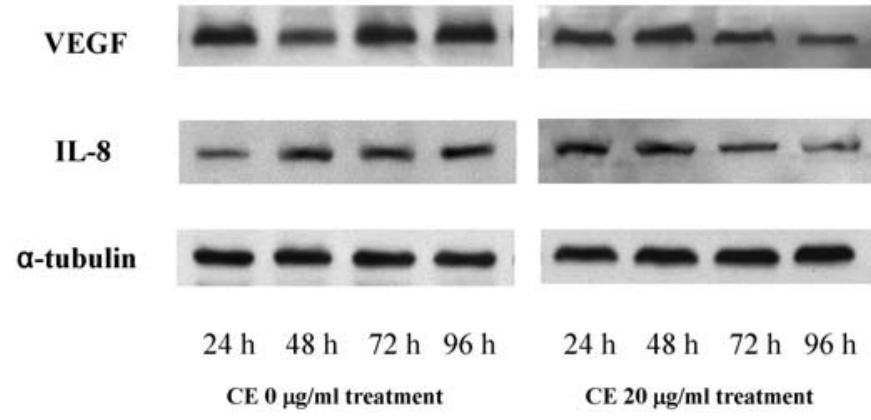

Figure 6. Expression of VEGF and IL-8 protein in Cepharanthine-treated cells. B88 cells were treated with $20 \mu \mathrm{g} / \mathrm{ml}$ Cepharanthine for $24-96 \mathrm{~h}$, and the cell lysates were obtained for Western blot analysis. Equal amount of cellular protein $(50 \mu \mathrm{g})$ was subjected to SDS-PAGE, followed by Western blot analysis for VEGF and IL-8. $\alpha$-tubulin was used as a control for equal protein load.

was administered daily at the dose of $40 \mathrm{mg} / \mathrm{kg}$ for 21 days, the tumor growth was significantly suppressed when compared with that of control (saline alone). During the experimental period, no loss of body weight was observed in the Cepharanthine treated group and control group (data not shown).

Effect of Cepharanthine on VEGF and IL-8 production, angiogenesis and $N F-\kappa B$ activation in vivo. We determined whether the production of VEGF and IL-8 was decreased, the angiogenesis was suppressed, and NF-кB activity was suppressed by the Cepharanthine administration in a nude mouse model. B88 tumors were resected and processed for immunohistochemical analyses of VEGF and IL- 8 expression, vascular formation and NF- $\mathrm{KB}$ activation using anti-VEGF, IL-8, CD34 and p65 antibodies respectively. As shown in Fig. 11 and
Table I. Microvessel density.

\begin{tabular}{lc}
\hline Tissue & Total vessels \\
\hline Control & $16.27 \pm 2.14$ \\
& \\
Cepharanthine & $12.16 \pm 1.78^{\mathrm{a}}$ \\
$10 \mathrm{mg} / \mathrm{kg}$ & $9.41 \pm 1.15^{\mathrm{a}}$ \\
$20 \mathrm{mg} / \mathrm{kg}$ & $4.28 \pm 0.63^{\mathrm{a}}$ \\
$40 \mathrm{mg} / \mathrm{kg}$ & \\
\hline
\end{tabular}

${ }^{\mathrm{a}} \mathrm{P}<0.01$ when compared with that of control by the Mann-Whitney $\mathrm{U}$ test. Microvessel density of B88 tumor lesions. Vascularity was quantified in the stroma close to the epithelium, up to $\sim 750 \mu \mathrm{m}$ from the basal lamina. Vessels $\pm 50 \mu \mathrm{m}$ in diameter were counted. The sum of small and large vessels is referred to as total vessels.

Table I, higher expression of VEGF and IL-8 was found in untreated control tumor lesions than in Cepharanthine treated tumors. In addition, expression of VEGF and IL- 8 was markedly decreased in the tumors given Cepharanthine (40 mg/kg). Consistent with the alteration of VEGF and IL-8 expression, untreated control tumors were highly vascularized, whereas tumors given Cepharanthine had a significant decrease in microvessel density (Table I). Moreover, expression of p65 was observed in the cytoplasm of Cepharanthine-treated tumors though expression of p65 was seen in the nuclei of untreated control tumor.

\section{Discussion}

We investigated whether Cepharanthine could suppress angiogenesis and growth of OSCC cells, and confirmed that 


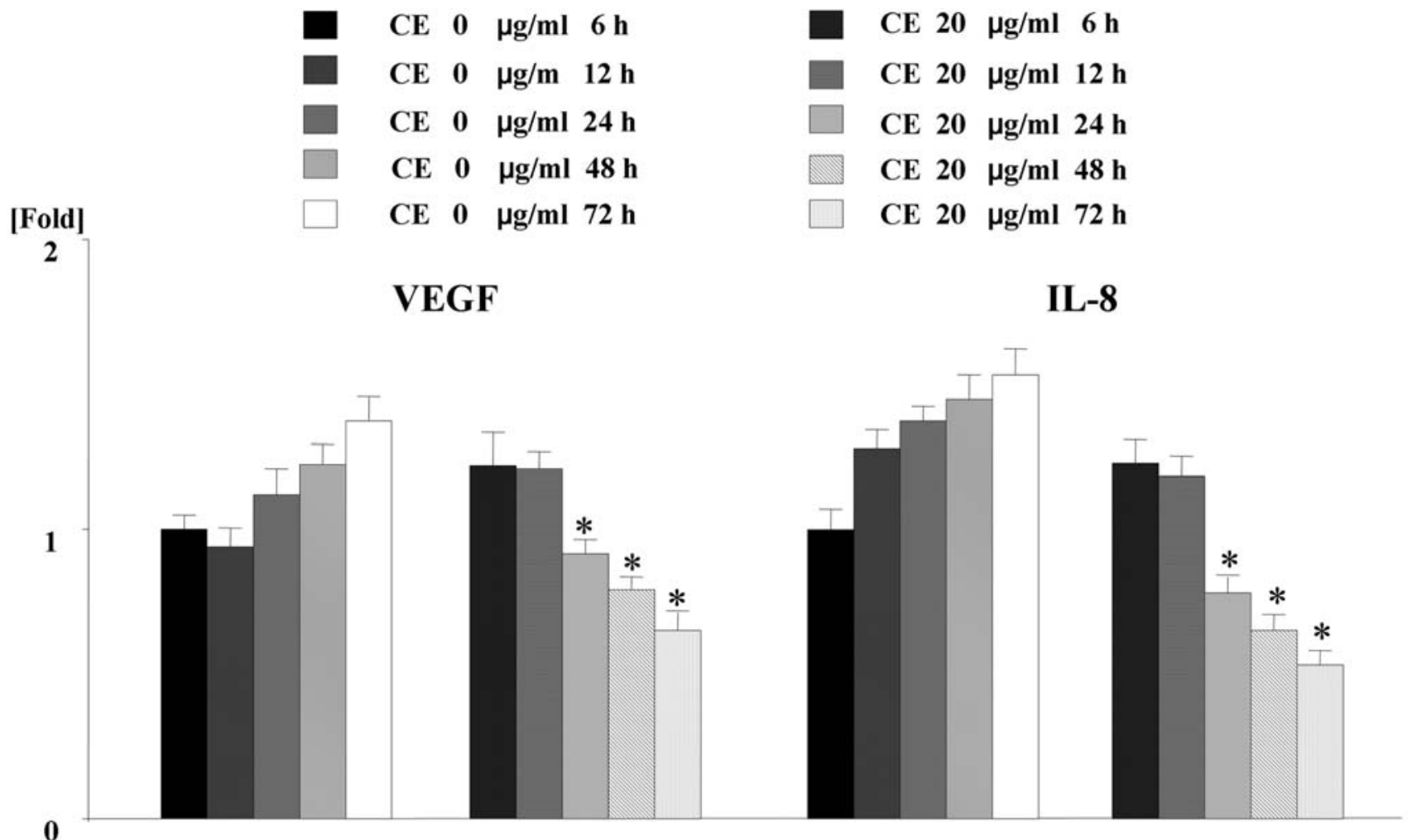

Figure 7. Quantitative real-time RT-PCR analysis of VEGF and IL-8 mRNA levels in B88 cells. The relative expression level of Cepharanthine-treated cells when compared with Cepharanthine-untreated cells is shown. ${ }^{*} \mathrm{P}<0.01$ when compared with that of control by Mann-Whitney U test.

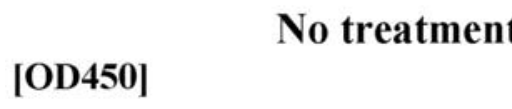

TNF- $\alpha$ treatment

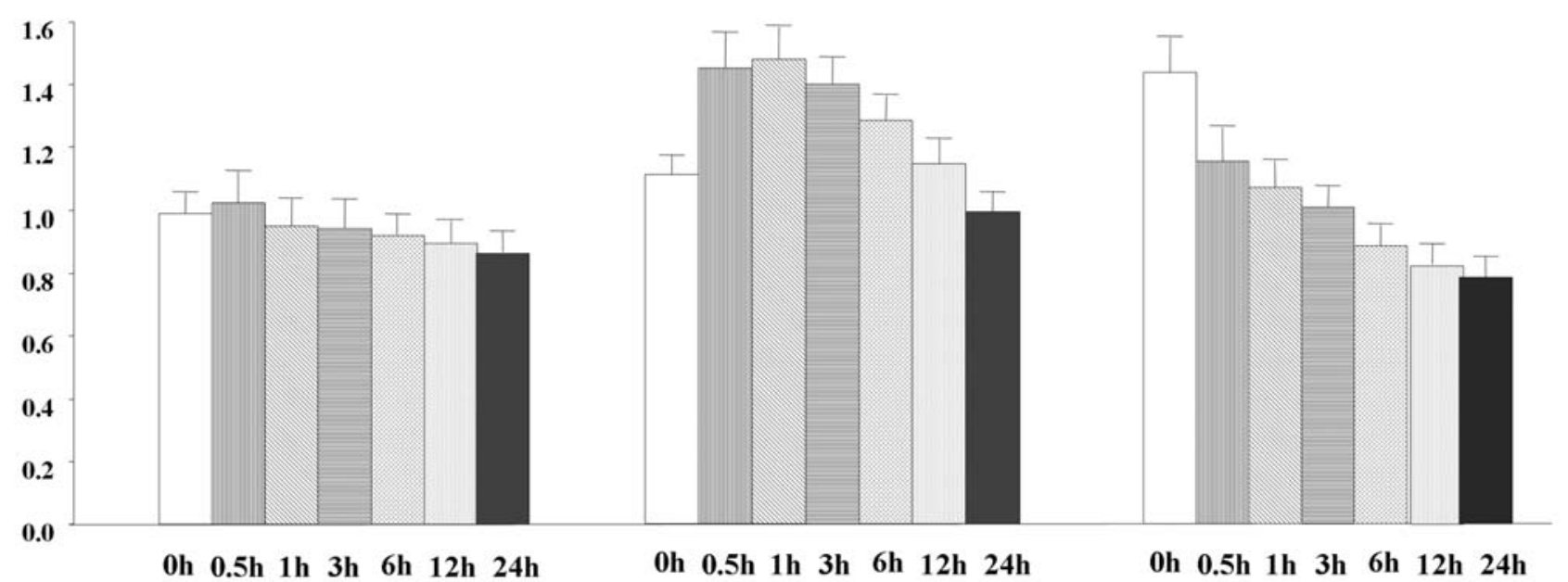

Figure 8. Effect of Cepharanthine on NF- $\mathrm{KB}$ binding activity. In the presence or absence of TNF- $\alpha$ for $0.5-24 \mathrm{~h}$ pretreatment, B88 cells were treated with

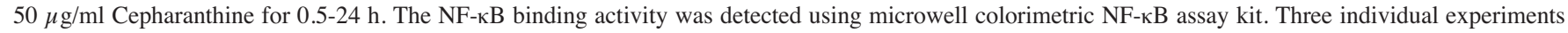
were performed, and the averages are shown (mean $\pm \mathrm{SD})$.

it does so by inhibiting the expression of VEGF and IL-8 involved in the blockade of NF- $\mathrm{NB}$ activity. We previously reported that Cepharanthine can exert a direct antitumor effect on solid tumors including adenosquamous cell carcinoma and OSCC. Briefly, we have clarified that Cepharanthine can exert antitumor effects by inducing G1 


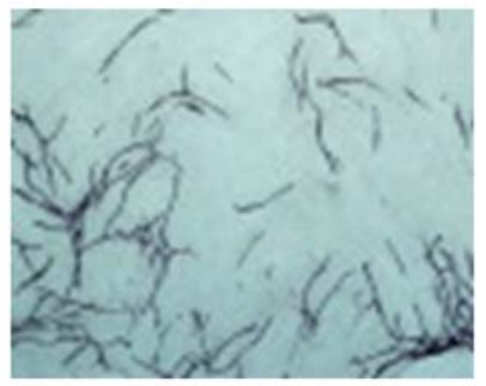

$\mathrm{CE} 0 \mu \mathrm{g} / \mathrm{ml}$

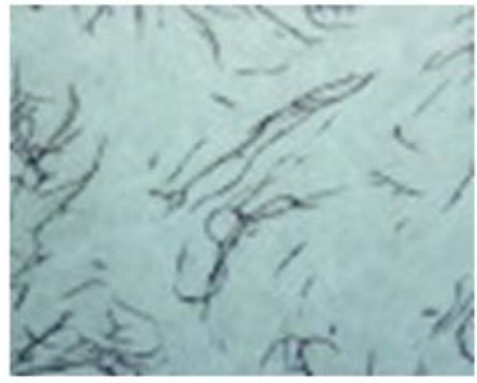

$\mathrm{CE} 1.0 \mu \mathrm{g} / \mathrm{ml}$

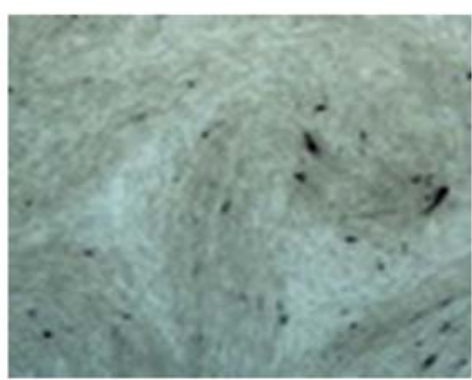

CE $5.0 \mu \mathrm{g} / \mathrm{ml}$

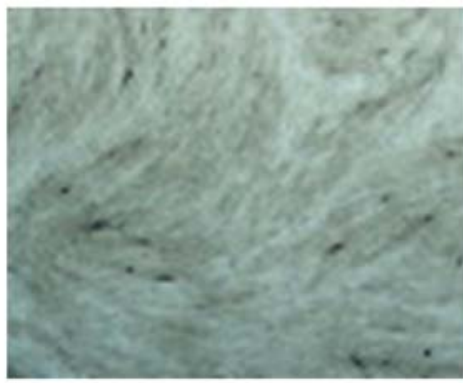

$\mathrm{CE} 10.0 \mu \mathrm{g} / \mathrm{ml}$

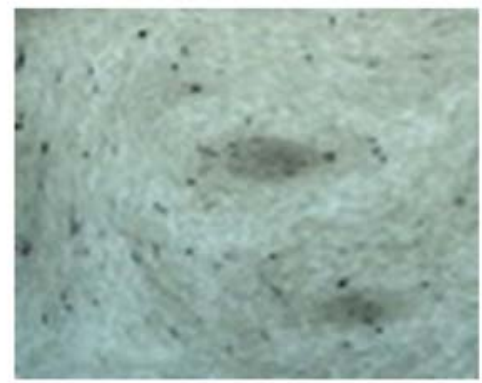

CE $20.0 \mu \mathrm{g} / \mathrm{ml}$

Figure 9. Effect of Cepharanthine on the tube formation by HUVECs. HUVECs were co-cultured with human fibroblasts as described in Materials and methods, and incubated for 11 days with or without Cepharanthine concomitantly to the addition of VEGF (10 ng/ml).

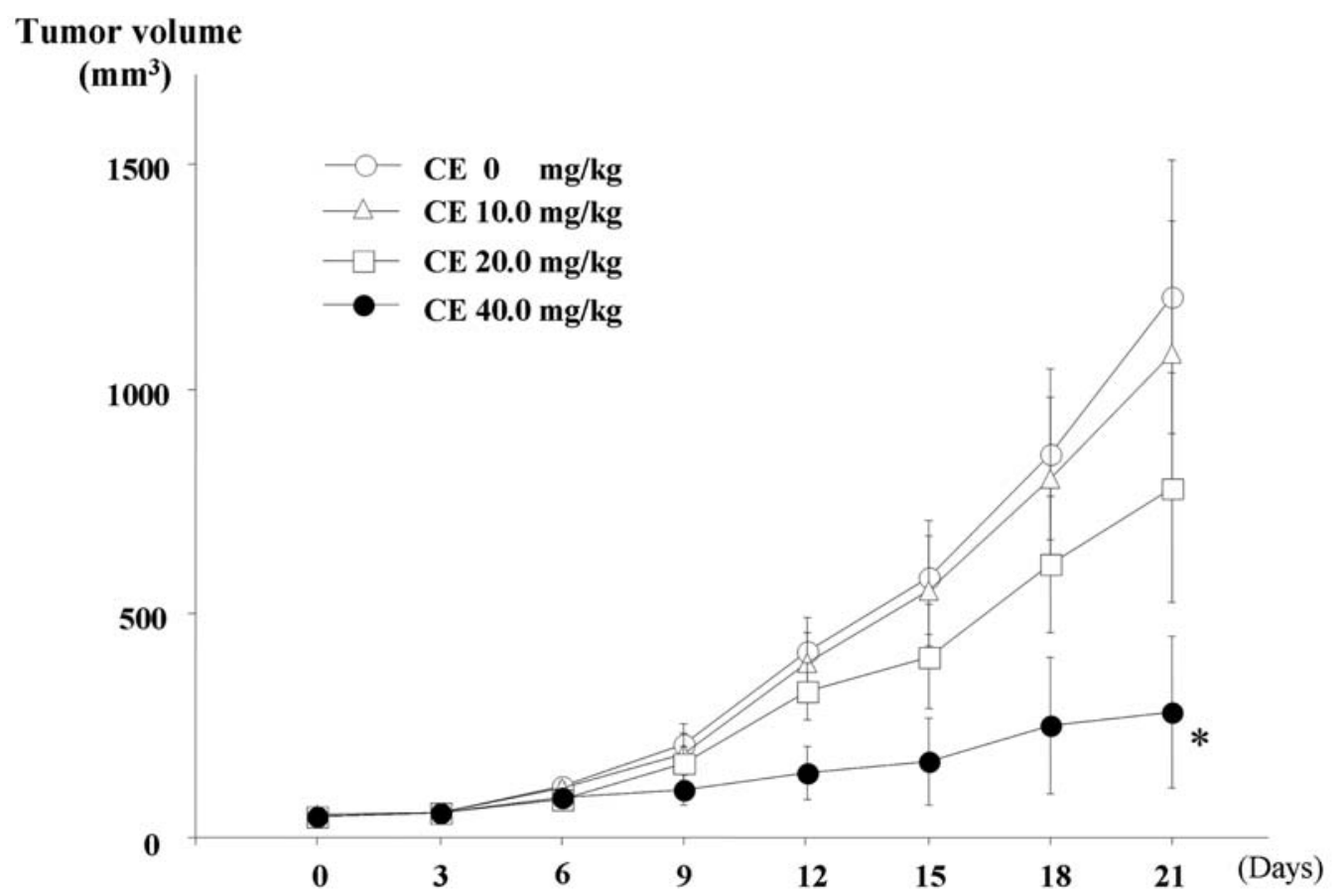

Figure 10. Tumor growth of B88 cells treated with or without Cepharanthine. Tumor cells (1x10 cells) were suspended in 0.1 ml of serum-free medium and injected into the subcutaneous tissue of nude mice. Sizes of the tumors were determined by first measuring length (L) and width (W) and then the tumor volume $\left(0.4 \times \mathrm{L} \mathrm{x} \mathrm{W}^{2}\right)$ was calculated. Each group had 5 mice. The values shown are the mean of five tumors $\left(\mathrm{mm}^{3}\right)$; bars; SD.

arrest via expression of cell cycle regulators such as $\mathrm{p} 21^{\mathrm{WAF} 1}$ or p27 $7^{\text {Kip } 1}(13,14)$. However, little is known about the other detailed mechanisms of antitumor activity of Cepharanthine in solid tumors.
Angiogenesis is though to have important roles in metabolic function and solid tumor growth, facilitating tumor invasion and metastasis $(30,31)$, and to be regulated by a number of growth factors with angiogenic activity. Tumor 


\section{CE $0 \mathrm{mg} / \mathrm{kg}$}
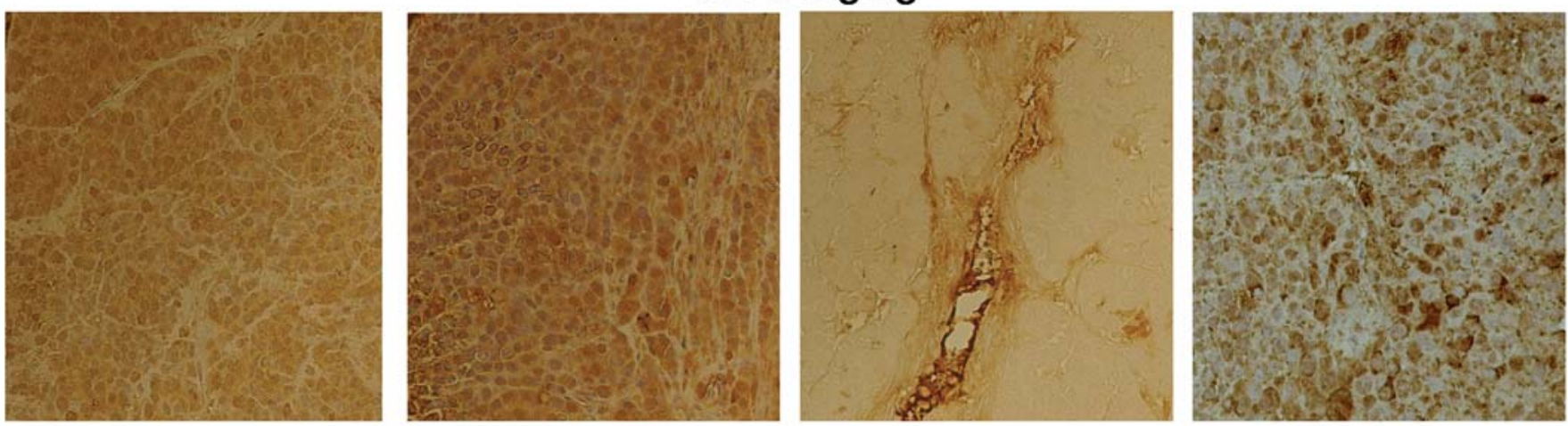

\section{$\mathrm{CE} 40 \mathrm{mg} / \mathrm{kg}$}

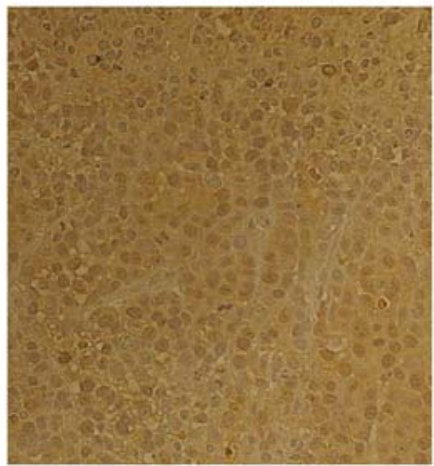

VEGF

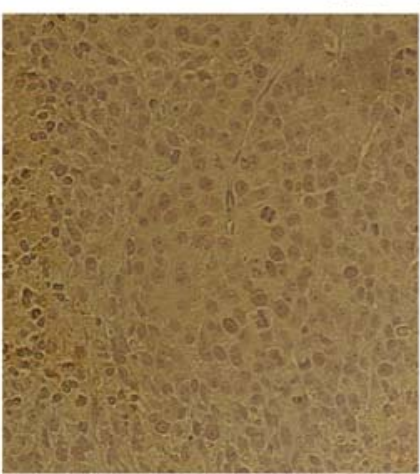

IL-8

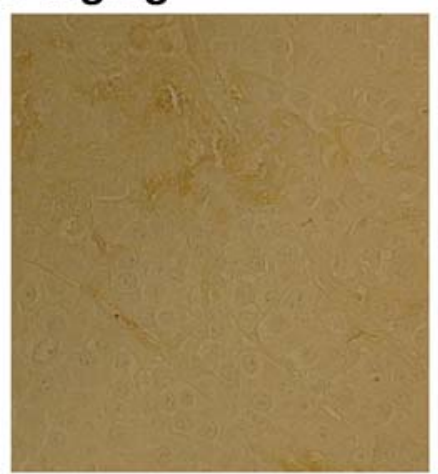

CD34

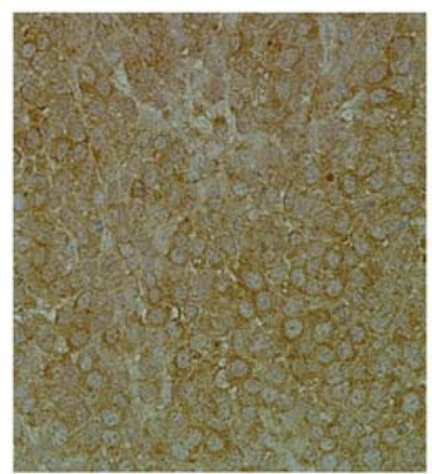

p65 NF-KB

Figure 11. Expression of VEGF, IL-8, CD34 and p65 protein in Cepharanthine-treated B88 tumors. B88 tumors were treated or untreated with $10-40$ mg/kg Cepharanthine. The expression of VEGF, IL-8, CD34 and p65 was detected with immunohistochemical staining using each antibody.

angiogenesis is controlled by angiogenic factors directly induced from tumor cells, as well as by factors indirectly induced from surrounding stromal tissues. Among several growth factors, VEGF seemed to play an important role in tumor angiogenesis of OSCC (32). Also, IL-8 has been shown to contribute to cancer progression by acting as a mitogenic and angiogenic factor (33). The role of IL-8 in OSCC was observed in several studies in which its expression has been strongly correlated with metastatic phenotype $(34,35)$. Briefly, IL-8 as well as VEGF must play an important role in tumor angiogenesis of OSCC.

Our results show that Cepharanthine treatment in cultured OSCC cells induced a decrease in the levels of VEGF mRNA and protein, followed by the suppression of the cell growth. Also, we found that mRNA and protein levels of IL-8 decreased following Cepharanthine treatment. Briefly, Cepharanthine was able to suppress the VEGF and IL-8 expression levels in OSCC cells. Moreover, anti-angiogenic effect of Cepharanthine was reconfirmed by an in vivo tumorigenicity assay in mice. As expected from its stronger growth inhibition, a significant suppression of tumor growth was detected in Cepharanthine-treated tumors when compared with that of control in vivo animal tumor model.

Interestingly, Okamoto et al reported that Cepharanthine might inhibit activation of NF- $\mathrm{KB}$ in monocytic cells (23). In addition, several previous studies have implicated that NF- $\mathrm{B}$ can upregulate VEGF and IL-8 transcription $(36,37)$. Huang et al demonstrated that inhibition of $\mathrm{NF}-\kappa \mathrm{B}$ activity by the expression of the inhibitor of nuclear factor- $\kappa \mathrm{B}(\mathrm{I \kappa B})$ super repressor suppressed the induction of IL-8 and VEGF in prostate, ovarian, and melanoma cancer cells (22,38-39). This inhibition also reduced tumorigenicity, angiogenesis, and metastasis of tumors formed from these cells. Bancroft et al reported very similar results for a human head and neck squamous cell carcinoma cell line (36). However, a later study from this same group showed that expression of IкBM blocked the induction of IL- 8 but not VEGF in head and neck squamous cell carcinoma cells treated with epidermal growth factor (40). There are conflicting studies on the correlation between inhibition of $\mathrm{NF}-\kappa \mathrm{B}$ activity and suppression of VEGF induction. Also, the inhibition of tumorigenicity by suppression of NF- $\mathrm{KB}$ activity had to occur by other mechanisms, such as inhibition of cell adhesion (41), inhibition of pro-inflammatory cytokine production (42), or inhibition of plasminogen activator and matrix metalloproteinase $(43,44)$, which contribute to neoplastic angiogenesis, growth, and metastasis. Briefly, suppression of NF- $\mathrm{\kappa B}$ activity may induce anti-angiogenesis without down-regulation of VEGF and IL-8. In this study, we detected that Cepharanthine inhibited TNF- $\alpha$ induced activation of NF- $\mathrm{NB}$ in OSCC cells. Suggesting that Cepharanthine has a potent inhibitor of NF-кB activation induced by TNF- $\alpha$. In conclusion, we showed that Cepharanthine could decrease angiogenesis, retarded tumor growth, and reduced formation of malignant ascites, in part 
through down-regulation of the angiogenic molecules VEGF and IL-8.

\section{Acknowledgements}

This study was supported in part by a Grant-in-Aid from the Japanese Ministry of Education, Science and Culture.

\section{References}

1. Parkin DM, Bray F, Ferlay J and Pisani P: Global cancer statistics, 2002. CA Cancer J Clin 55: 74-108, 2005.

2. Inagi K, Takahashi H, Okamoto M, Nakayama M, Makoshi T and Nagai H: Treatment effects in patients with squamous cell carcinoma of the oral cavity. Acta Otolaryngol 122 (Suppl 547): 25-29, 2002.

3. Shingaki S, Takada M, Sasai K, Bibi R, Kobayashi T, Nomura T and Saito C: Impact of lymph node metastasis on the pattern of failure and survival in oral carcinomas. Am J Surg 185: 278-284, 2003.

4. Tomita M, Fujitani K and Aoyagi Y: Synthesis of $d l$ cepharanthine. Tetrahedron Lett 13: 1201-1206, 1967.

5. Saito R, Tsuchiya S, Ishizuka T, Fueki N, Ezawa K, Minato K, Nakano H, Takise A, Kurihara M and Fueki R: Clinical effects of cepharanthine (Ceph.) on leukopenia by chemotherapy in lung cancer patients. J Jpn Soc Cancer Ther 24: 4587-4593, 1989.

6. Ono M: Antitumor effect of cepharanthine: activation of regional lymph node lymphocytes by intratumoral administration. Clin Immunol 19: 1061-1064, 1987.

7. Morioka S, Ono M, Tanaka N and Orita K: Synergistic activation of rat alveolar macrophages by cepharanthine and OK-432. Jpn J Cancer Chemother 12: 1407-1407, 1985.

8. Asaumi J, Kawasaki S, Nishikawa K, Kuroda M and Hiraki Y: Effects of hyperthermia and cepharanthine on adriamycin accumulation with change in extracellular $\mathrm{pH}$. Int $\mathrm{J}$ Hyperthermia 11: 27-35, 1995

9. Nishikawa K, Asaumi J, Kawasaki S, Kuroda M, Takeda Y and Hiraki Y: Influence of cepharanthine on the intracelluar accumulation of adriamycin in normal liver cells and spleen cells of mice in vitro and in vivo. Anticancer Res 17: 3617-3622, 1997.

10. Hotta T, Tanimura H, Yamaue H, Iwahashi M, Tani M, Tsunoda T, Tamai M, Noguchi K, Mizobata S, Arii K and Terasawa $\mathrm{H}$ : Modulation of multidrug resistance by cepharanthine in fresh human gastrointestinal tumor cells. Oncology 54: 153-157, 1997.

11. Hotta T, Tanimura H, Yamaue H, Iwahashi M, Tani M, Tsunoda T, Noguchi K, Mizobata S and Terasawa H: Synergistic effects of tamoxifen and cepharanthinee for circumventing the multidrug resistance. Cancer Lett 107: 117-123, 1996.

12. Furusawa S, Wu J, Fujimura T, Nakano S, Nemoto S, Takayanagi M, Sasaki K and Takayanagi Y: Cepharanthinee inhibits proliferation of cancer cells by inducing apoptosis. Methods Find Exp Clin Pharmacol 20: 87-89, 1998.

13. Harada K, Bando T, Yoshida $\mathrm{H}$ and Sato M: Characteristics of antitumour activity of cepharanthin against a human adenosquamous cell carcinoma cell line. Oral Oncol 37: 643-651, 2001.

14. Harada K, Supriatno, Yamamoto S, Kawaguchi S, Yoshida H and Sato M: Cepharanthine exerts antitumor activity on oral squamous cell carcinoma cell lines by induction of p27 Kip1. Anticancer Res 23: 1441-1448, 2003.

15. Williams JK, Carlson GW, Cohen C, Derose PB, Hunter S and Jurkiewicz MJ: Tumor angiogenesis as a prognostic factor in oral cavity tumors. Am J Surg 168: 373-380, 1994.

16. Leung DW, Cachianes G, Kuang WH, Goeddel DV and Ferrara N: Vascular endothelial growth factor is a secreted angiogenic mitogen. Science 246: 1306-1309, 1989.

17. Guo D, Jia Q, Song HY, Warren RS and Donner DB: Vascular endothelial cell growth factor promotes tyrosine phosphorylation of mediators of signal transduction that contain SH2 domains. Association with endothelial cell proliferation. J Biol Chem 270: 6729-6733, 1995.

18. Smith BD, Smith GL, Carter D, Sasaki CT and Haffty BG: Prognostic significance of vascular endothelial growth factor protein levels in oral and oropharyngeal squamous cell carcinoma. J Clin Oncol 18: 2046-2052, 2000.
19. Maeda T, Matsumura S, Hiranuma H, Jikko A, Furukawa S Ishida $\mathrm{T}$ and Fuchihata $\mathrm{H}$ : Expression of vascular endothelial growth factor in human oral squamous cell carcinoma: its association with tumour progression and p53 gene status. J Clin Pathol 51: 771-775, 1998.

20. Strieter RM, Kunkel SL, Elner VM, Martonyi CL, Koch AE, Polverini PJ and Elner SG: Interleukin-8. A corneal factor that induces neovascularization. Am J Pathol 141: 1279-1284, 1992.

21. $\mathrm{Hu}$ DE, Hori $\mathrm{Y}$ and Fan TP: Interleukin-8 stimulates angiogenesis in rats. Inflammation 17: 135-143, 1993.

22. Huang S, Robinson JB, Deguzman A, Bucana CD and Fidler IJ: Blockade of nuclear factor-kappaB signaling inhibits angiogenesis and tumorigenicity of human ovarian cancer cells by suppressing expression of vascular endothelial growth factor and interleukin 8. Cancer Res 60: 5334-5339, 2000.

23. Okamoto M, Ono M and Baba M: Potent inhibition of HIV type 1 replication by an antiinflammatory alkaloid, cepharanthine, in chronically infected monocytic cells. AIDS Res Hum Retroviruses 14: 1239-1245, 1998.

24. Supriatno, Harada K, Hoque MO, Bando T, Yoshida H and Sato M: Overexpression of $\mathrm{p} 27^{\mathrm{Kip} 1}$ induces growth arrest and apoptosis in an oral cancer cell line. Oral Oncol 38: 730-736, 2002.

25. Schor AM, Schor SL and Allen TD: Effects of culture conditions on the proliferation, morphology and migration of bovine aortic endothelial cells. J Cell Sci 62: 267-285, 1983.

26. Carmichael J, DeGraff WG, Gazdar AF, Minna JD and Mitchell JB: Evaluation of a tetrazolium-based semiautomated calorimetric assay: Assessment of chemosensitivity testing. Cancer Res 47: 936-942, 1987.

27. Renard P, Ernest I, Houbion A, Art M, Le Calvez H, Raes M and Remacle J: Development of a sensitive multi-well colorimetric assay for active NF-kappaB. Nucleic Acids Res 29: E21, 2001.

28. Pazouki S, Chisholm DM, Adi MM, Carmichael G, Farquharson M, Ogden GR, Schor SL and Schor AM: The association between tumour progression and vascularity in the oral mucosa. J Pathol 183: 39-43, 1997.

29. Tamatani T, Azuma M, Aota K, Yamashita T, Bando T and Sato M: Enhanced IkappaB kinase activity is responsible for the augmented activity of NF-kappaB in human head and neck carcinoma cells. Cancer Lett 171: 165-172, 2001.

30. Folkman J: What is the evidence that tumors are angiogenesis dependent? J Natl Cancer Inst 82: 4-6, 1990.

31. Weinstat-Saslow D and Steeg PS: Angiogenesis and colonization in the tumor metastatic process: basic and applied advances. FASEB J 8: 401-407, 1994.

32. Li C, Shintani S, Terakado N, Klosek SK, Ishikawa T, Nakashiro K and Hamakawa H: Microvessel density and expression of vascular endothelial growth factor, basic fibroblast growth factor, and platelet-derived endothelial growth factor in oral squamous cell carcinomas. Int J Oral Maxillofac Surg 34: $559-565,2005$.

33. Xie K: Interleukin- 8 and human cancer biology. Cytokine Growth Factor Rev 12: 375-391, 2001

34. Gokhale AS, Haddad RI, Cavacini LA, Wirth L, Weeks L, Hallar M, Faucher J and Posner MR: Serum concentrations of interleukin-8, vascular endothelial growth factor, and epidermal growth factor receptor in patients with squamous cell cancer of the head and neck. Oral Oncol 41: 70-76, 2005.

35. Watanabe $H$, Iwase $M$, Ohashi $M$ and Nagumo $M$ : Role of interleukin-8 secreted from human oral squamous cell carcinoma cell lines. Oral Oncol 38: 670-679, 2002.

36. Bancroft CC, Chen Z, Dong G, Sunwoo JB, Yeh N, Park C and Van Waes C: Coexpression of proangiogenic factors IL-8 and VEGF by human head and neck squamous cell carcinoma involves coactivation by MEK-MAPK and IKK-NF-kappaB signal pathways. Clin Cancer Res 7: 435-442, 2001

37. Yoshida A, Yoshida S, Khalil AK, Ishibashi $\mathrm{T}$ and Inomata $\mathrm{H}$ : Role of NF-kappaB-mediated interleukin-8 expression in intraocular neovascularization. Invest Ophthalmol Vis Sci 39: 1097-1106, 1998.

38. Huang S, Pettaway CA, Uehara H, Bucana CD and Fidler IJ: Blockade of $N F-\kappa B$ activity in human prostate cancer cells is associated with suppression of angiogenesis, invasion, and metastasis. Oncogene 20: 4188-4197, 2001.

39. Huang S, DeGuzman A, Bucana CD and Fidler IJ: Nuclear factor-B activity correlates with growth, angiogenesis, and metastasis of human melanoma cells in nude mice. Clin Cancer Res 6: 2573-2581, 2000. 
40. Bancroft CC, Chen Z, Yeh J, Sunwoo JB, Yeh NT, Jackson S, Jackson C and Van Waes C: Effects of pharmacologic antagonists of epidermal growth factor receptor, PI3K and MEK signa kinases on NF-kB and AP-1 activation and IL-8 and VEGF expression in human head and neck squamous cell carcinoma lines. Int J Cancer 99: 538-548, 2002.

41. Higgins KA, Perez JR, Coleman TA, Dorshkind K, McComas WA, Sarmiento UM, Rosen CA and Narayanan R: Antisense inhibition of the p65 subunit of NF-kappa B blocks tumorigenicity and causes tumor regression. Proc Natl Acad Sci USA 90: 9901-9905, 1993.

42. Duffey DC, Chen Z, Dong G, Ondrey FG, Wolf JS, Brown K, Siebenlist $U$ and Van Waes C: Expression of a dominant-negative mutant inhibitor-kappaBalpha of nuclear factor-kappaB in human head and neck squamous cell carcinoma inhibits survival, proinflammatory cytokine expression, and tumor growth in vivo. Cancer Res 59: 3468-3474, 1999.
43. Wang W, Abbruzzese JL, Evans DB and Chiao PJ: Overexpression of urokinase-type plasminogen activator in pancreatic adenocarcinoma is regulated by constitutively activated relA. Oncogene 18: 4554-4563, 1999.

44. Bond M, Fabunmi RP, Baker AH and Newby AC: Synergistic upregulation of metalloproteinase-9 by growth factors and inflammatory cytokines: an absolute requirement for transcription factor NF-kappaB. FEBS Lett 435: 29-34, 1998 